\title{
Rescue Works in Case of Fire in Tall Buildings in Riga
}

\author{
Jeḷena Malahova ${ }^{1}$, Kārlis Ketners ${ }^{2}$, Jānis Ieviṇš ${ }^{3}$, Mihails Antonovs ${ }^{4}$, \\ ${ }^{1-3}$ Riga Technical University, ${ }^{4}$ State Fire and Rescue Service of Latvia
}

\begin{abstract}
The article proposes the rescue works in case of fire in tall buildings in Riga, the Republic of Latvia. The subject of the present study is a problem of tall buildings in the context of fire safety, fire extinguishing and performance of rescue works, while multi-storey residential houses have been chosen as the study object. The study presents the analysis of a multi-storey building with number of storeys over 10 (high-rise building) since just such buildings are characterized by increased fire hazard and more difficult fire extinguishing and rescue works. Within the framework of the performed study, one of tall buildings in Riga has been analyzed: multi-storey residential apartment building at 11 Lielirbes Street.
\end{abstract}

Keywords - Rescue works in case of fire, tactical plan, tall building.

\section{INTRODUCTION}

To achieve the set objective, the following tasks should be carried out:

- summary of statistical information (the number of fire cases and fire origin points, fire safety inspections in tall buildings) and analysis of literature sources;

- identification of general problems in performance of rescue works in tall buildings and their fire hazards;

- summary classification of multi-storey residential apartment houses and facts about the world highest buildings;

- systematization of fire safety solutions for tall buildings;

- analysis of the example of the study subject-matter;

- development of tactical plans for the performance of rescue works.

Technology and process of construction are progressively developing and we can see the towns and cities growing while engineers are implementing even more various projects: buildings become bigger, higher and more grandiose. Due to the scarcity of spare area and growing cost of land, cities are growing upwards and the number of storeys is gradually growing.

Each year fires occur in tall buildings and people die in Latvia and all over the word. When looking at an architect's creation, the might of a building, we are fascinated by its power but we cannot even imagine what an incommensurable danger hides behind the mirror-smooth windows. Although many people would be responsible and try not to allow fire break-out, sometimes it happens.

Often the owner (manager) of a residential house or building also allows violations of fire safety, since they cannot find a mutual compromise with the inhabitants, thus causing even more problems to the rescue service in saving the life of people who are within the residential areas, while the time necessary to get into an apartment is very precious for those people in the apartment or nearby.

Studying this problem, we can conclude that people mix up the fire risk assessment with the labour risk assessment. As well, there is no information where an objective fire risk assessment could be viewed and used as an example. Cases are known when incompetent companies develop fire risk assessment procedures sometimes even not including all hazard factors that are present at the object, or also such assessment procedures are developed following the same pattern.

Therefore, the subject of the present study is a problem of tall buildings in the context of fire safety, fire extinguishing and performance of rescue works while multi-storey residential houses have been chosen as the study object. The study presents the analysis of a multi-storey building with the number of floors over 10 (high-rise building) since just such buildings are characterized by increased fire hazard and more difficult fire extinguishing and rescue works. Within the framework of the performed study, one of tall buildings in Riga has been analyzed: multi-storey residential apartment building at 11 Lielirbes Street.

\section{PeCuliar FeAtures IN OPERATION AND FIRE SAFETy OF TALL BUILDINGS IN LATVIA}

The existing regulatory base provides for the arrangement of fire safety system in newly built tall buildings. While tall buildings that were commissioned in the Soviet times and in the 90 s of the past century were subject to standards and building codes, under which the buildings were put into operation and which do not in full meet the EU requirements. Operation rules still stipulate that the access roads to the tall buildings are positioned only at one façade side, while it causes great problems for the fire and rescue service in getting to the victims from the other side, private property issues compounding to the problem: private cars parked along the building façade. Each year fire safety inspectors examine the multi-storey residential houses, and each year new problems with the observance of fire safety regulations appear, while the old ones remain unsolved. Fire safety supervision in multistorey residential apartment buildings is complicated enough since inspectors of the State Fire and Rescue Service cannot enforce each private person to observe their own safety.

Therefore, fire safety and fire extinguishing at all times remains a topical issue. This topicality is associated with the necessity to solve complex fire safety problems in tall 
buildings during the project design phase and also at the operation period. There is a possibility of increasing risk to the inhabitants and maintenance of fire risk within the safety range. It is necessary to supervise the observance of fire safety regulations, as well as to perform fire extinguishing and rescue works during the operation period.

Tall buildings gained popularity in the construction industry after 1871 fire in Chicago where the most part of buildings burned down. Thus, Chicago was destined to become a motherland of skyscrapers. In 1885 upon the launch of the project of architect William Le Baron Jenney a building of the Insurers Association was erected, which stood until 1891.

In late 19th and early 20th century, as a result of growing populating and demographic processes as well as due to economic upsurge and growing cost of urban land, construction of tall buildings began in the USA as well as in other countries.

In those years, tall buildings were erected with wide walls since all weight was borne by the bearing walls. However, skeleton-type construction helped to solve this problem. Since the main load was applied to the skeleton, durability of walls was not so important any longer.

After World War II, tall buildings were erected using modern methods. At the same time, such buildings were not occupied only by office areas any longer, the premises started to get occupied by trade centres, cinema theatres, shops, restaurants, etc.

In the second half of the 20th century, high-rise buildings started little by little conquering the world. In many places intensive construction of tall buildings started after military actions that had ruined towns and cities.

In the opinion of experts, the fire ladder will not help if all the requirements and standards that regulate the construction of such projects all over the world are not followed. In emergency situations, it is practically impossible to evacuate the skyscraper dwellers. Mechanical ladder trucks allow evacuating people from the height of up to $30 \mathrm{~m}$. It is envisaged that evacuation of people from the height above this mark will be carried out by means of helicopters. Of course, it is absolutely impossible to ensure the safety of all people in emergency situations at such height.

Within the recent three years, the construction industry has been developing rapidly. More building having over 20 storeys have been erected in Riga. In 2011, the Riga City Building Board accepted more than 3,800 construction designs in total providing for the commencement of new building projects and performance of engineering and technical works.

The European Directive for the Construction Products 89/106 EEC establishes the unified safety requirements with regard to the construction products (building materials, building structures) and construction products duly certified with CE marking (this Directive was introduced in Latvia by the Cabinet of Ministers Regulation No. 181 of 30 April 2001 "Procedures for the Conformity Assessment of Construction Products in the Regulated Sphere" and by the Latvian Building Code LBN 006-00 "Essential Requirements for Structures").

In many construction projects the structures and materials are employed, which are not as fire-resistant as promised by their sellers and, most important, are not durable enough to ensure the fire safety for a longer time. Positive examples, in turn, should be searched for among public buildings, the construction of which is financed by the European investors. In these buildings, the modern adequate fire safety requirements are also met.

In the capital city of Latvia the over-nine-storey building development only started in late 19th century. The first project of this kind on the background of the surrounding buildings in Riga looked like a huge monster. However, the inhabitants got used to it, and with time the number of storeys in buildings started to grow.

Today, there are no real skyscrapers in Riga according the world standards, mainly twenty- and thirty-storey buildings are erected.

The number of tall buildings constructed is increasing ever more rapidly. 1) They are evolving in height, construction materials, use, and compartmental composition. According to The Skyscraper Center (maintained and updated by the Council on Tall Buildings and Urban Habitat), Latvian tallest buildings and towers are located in Riga (Table I) [1]. Since 2000s, the number of multi-storey buildings in Riga increased rapidly. The authors agree with the Society of Fire Protection Engineers, Guidelines for Designing Fire Safety in Very Tall Buildings, Public Review Draft, March 2012 (Cowlard, Adam, et al. "Fire safety design for tall buildings." Procedia Engineering 62 (2013): 169-181.) that the tall building of today is a completely different entity compared to that of a decade ago with the propensity for change even greater in the immediate future. Advancements in structural engineering have made the increase in height, size and complexity possible, ensured the reduction of cost and carbon footprint as well as have facilitated architectural imagination and economic versatility of these buildings. What is coming is considered the era of tall buildings, the recent explosion in numbers has caused a number of engineers and governmental organizations to look at this genre with specific focus, not least from the perspective of fire safety [1].

One of the advantages of tall buildings is the possibility to theoretically make a city more compact, consolidating a big number of apartments at the same place; however, on the other hand, and in opinion of the authors, tall buildings are not typical for Riga. 
TABLE I

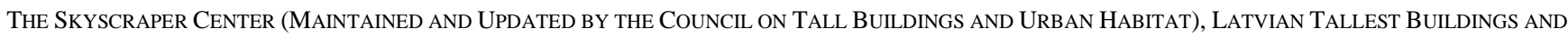
TOWERS ARE LOCATED IN RIGA

\begin{tabular}{|c|c|c|c|c|c|c|}
\hline Building Name & $\begin{array}{l}\text { Height } \\
\text { (m) }\end{array}$ & Floors & Completed & Material & Status & Usage \\
\hline Riga TV Tower & 368 & - & 1987 & steel & Completed & telecommunications / panorama tower \\
\hline St. Peter's Church & 123 & - & 1746 & masonry & Completed & religious \\
\hline Swedbank Central Office & 121 & 27 & 2004 & steel & Completed & office \\
\hline Panorama Plaza II & 114 & 32 & 2007 & concrete & Completed & residential \\
\hline Academy of Sciences & 108 & 21 & 1955 & composite & Completed & education \\
\hline Z-tornis B & 107 & 28 & 2015 & concrete & Topped out & office \\
\hline Panorama Plaza I & 99 & 27 & 2006 & concrete & Completed & residential \\
\hline Da Vinci & 95 & 27 & - & concrete & On hold & residential / office \\
\hline Ministry of Agriculture Building & 92 & 26 & 1976 & & Completed & office \\
\hline Latvijas Televizija & 89 & 22 & 1987 & & Completed & office \\
\hline AstraLux & 81 & 24 & 2007 & concrete & Completed & residential \\
\hline Solaris I & 78 & 25 & 2005 & concrete & Completed & residential \\
\hline$\underline{\text { Solaris II }}$ & 78 & 25 & 2005 & concrete & Completed & residential \\
\hline Preses Nams & 77 & 22 & 1977 & & Completed & office \\
\hline
\end{tabular}

TABLE II

Minimal LiMit VALUES OF FIRE RESISTANCE OF STRUCTURES

\begin{tabular}{|l|l|l|l|l|}
\hline \multirow{2}{*}{$\begin{array}{l}\text { Fire safety degree (in } \\
\text { brackets - previously } \\
\text { used denotation) }\end{array}$} & \multicolumn{3}{|l|}{ Minimal limit values of fire resistance (numerator, minutes) and combustibility groups (denominator) of structures } \\
\cline { 2 - 5 } & Walls & $\begin{array}{l}\text { stair landings, beams, stair } \\
\text { steps, staircase spans }\end{array}$ & $\begin{array}{l}\text { Interfloor structure panels, } \\
\text { coverings (incl. with insulation) } \\
\text { and other bearing overlapping } \\
\text { elements }\end{array}$ \\
\cline { 2 - 5 } & $\begin{array}{l}\text { bearing and } \\
\text { those of } \\
\text { staircase }\end{array}$ & $\begin{array}{l}\text { inner, not bearing } \\
\text { (partition walls) }\end{array}$ & $60 /$ & $45 /$ \\
2.(II) & $120 /$ & $15 /$ & noncombustible \\
& noncombustible & noncombustible & & noncombustible \\
\hline
\end{tabular}

One of the problems with tall buildings is rocking due to wind action. There are certain tall buildings in the world, constructive solution of which allows for minor oscillations due to wind; however, according to experts, in Latvia where for the time being no buildings have been erected higher than 20-30 storeys, the wind effect upon structures of these buildings is not essential, and a human will not feel the vibration when being on the upper storeys.

Indoor areas with a wide southward glazing will have problems with summer overheating. Various solutions of the problem are available [16], [17]:

1. installation of air cooling devices which, however, will increase the operational costs;

2. construction of oriels, which will physically shadow the sun;

3. use of louvers, curtains and sunray reflecting films these solutions partly help overcoming the problem, but do not solve the it completely.

On the other hand, a balcony or a terrace on lower or higher storeys is provided with the rails of equal height (about $1 \mathrm{~m}$ ).

Fire safety is of crucial importance in tall buildings, and to a great extent this responsibility is borne by the designers.
Therefore, a well thought-out layout in the building should be provided and all normative requirements should be followed: correct evacuation zones should be singled out and escape routes should be provided for, which are not only marked on the layout, but actually function and people can use them.

The present topic is chosen in view of rapid growth in number of high-rise buildings. Studying the existing regulatory base in the Latvian legislation, we have arrived at a conclusion that essential problems in this field are present, although Paragraph 6.7. of Regulation No. 82 of the Cabinet of Ministers of the Republic of Latvia of 17 February 2004 "Fire Safety Regulations", requires “... to assess the risk of possible fire and, basing on it, to develop and implement the fire safety measures at the project". The risk assessment for tall buildings in Latvia is a topical problem since new technologies open new opportunities, and therewith new problems appear.

Due to various circumstances, the number of accidents within definite time intervals, when the State Fire and Rescue Service responds and/or participates in the liquidation of emergency consequences, differs, and also the consequences may vary much, which is evidenced by the statistics on fires 
and their consequences, summarized in the present study (see Table II).

Statistics of the State Fire and Rescue Service evidences that 7,183 fires were registered within nine months of 2014, which is by $9 \%$ more than within the same period of 2013. Of the registered 7,183 fires, 2,663 broke out in dwelling houses, demonstrating $5 \%$ growth. 85 people lost their life in fire disasters, which is by $11 \%$ less than within the same period of 2013, while 188 people suffered in fires and in Riga 30 people died in fire disasters, in towns of the country -10 , but in rural districts 45 people lost their life. [10], [11], [12]

Officials for fire safety supervision and civil defense in territorial structural fire safety units have carried out inspections in tall buildings. In total, 267 tall buildings were inspected in 2014. Fire safety inspections demonstrate that the situation has deteriorated compared to 2013.

Most serious violations [10], [11], [12] were the following:

- fire safety induction meeting - not performed at 103 objects (in 2013 - 101 objects);

- measurements of electric installation insulation resistance not performed at 126 objects (in 2013 - 151 objects), performed partly at 11 objects (in $2013-11$ objects);

- emergency exits - nonconforming at 29 objects (in 2013 68 objects);

- provision of objects with safety signs - not provided at 84 objects (in 2013 - 129 objects);

- automatic fire detection system and alarm system - not arranged at 79 objects (in 2013 - 60 objects), arranged partly at 22 objects (in $2013-46$ objects).

Taking into consideration the statistical data, it can be concluded that most fires still occur due to human negligence. People often want to save fire safety means, not thinking about possible hazards. Fires most often happen in the buildings where people live, since fire safety in private apartments is not controlled enough compared to building where enterprises are situated.

Only after fire accident a detailed and thorough analysis is carried out: how the service was acting, what violations were made. However, compared to multi-storey residential apartment buildings training takes place much rarer since it will be never possible to carry out the practical experiments in order to analyze all possible versions. Also, as people by their nature are lazy and State Fire Safety Service cannot enforce every inhabitant to voluntarily participate in the practical trainings, which makes it difficult to organize such experiment that would be close to reality.

\section{3. FIRE HAZARDS AND PECULIARITIES OF FIRE SPREAD IN TALL BUILDINGS}

Fire hazards of buildings may change with time, depending on the technical condition of fire safety equipment, changes in technological process, re-profiling of building spaces and other reasons.

In accordance with the Latvian Building Codes, a tall building is a building having 10 and more storeys. Compared to other buildings, tall buildings distinguish in design features and increased fire hazards associated with specific factors $[13,14,15]$.
Difference of multi-storey residential buildings from regular buildings is their increased fire hazards that have occurred as the result of a great height, layout and design type of storeys, big number of vertical communications and power equipment, and large volume of combustible materials (furniture, plastering, etc.) [6].

Special fire hazards are present in those multi-storey buildings where polymer building materials have been widely used in their construction, since most plastic materials are combustible and during the combustion process they emit poisonous and toxic combustion products that may pose great danger to human life.

In accordance with the structural layout, multi-storey buildings may be of a corridor type or have a free layout, single- or multi-section residential buildings.

Tall buildings are charaterized by a rapid fire spread from one storey to another along the communications, windows, as well as within a storey where the fire has broken out, especially if the building has a corridor-type layout. Combustion products of the fire at great speed uprush along the staircases, elevator and technological wells, which act as smoke flues during the fire and create the "chimney effect" with upward draw, and as a result of insufficient ventilation, layers of combustion products may be formed on top storeys (see Fig. 1).

As a result of convection, heat energy and smoke gases move upwards, to the top point of the building - up to the ceiling or roof. Retained heat energy, smoke and smoke gases accumulate and particles cooled as the result of their exchange gradually move downwards, spreading all over the building spaces [18].

Smoke accumulation, which usually is characteristic for top storeys of buildings, does not appear in tall buildings until emission of heat amount is sufficient to lift the stratified smoke gases clouds from lower storeys upwards.



Fig.1. Spread of combustion products over storeys and spaces of the building. 
During the fire, a properly arranged ventilation system of the building reduces the possibility of fumigation of the building spaces, which, in turn, decreases the combustion spread speed, allowing the heated gases to flow out of the building (at least for a short time). But even with properly arranged ventilation, if the fire is not extinguished soon after the ventilation openings are made on the burning storey of the building, the fresh air inflow will only enhance the combustion.

Combustion products of the fire also spread through improperly sealed confining structures.

The priority of fire safety in tall buildings is the provision of human safety. Most people, especially inhabitants of hotels, do not know peculiar features of the layout, places of emergency exits and where personal protection equipment is located.

Staircases in such buildings are mainly used only on the first three storeys, almost all vertical people relocation load is laid upon elevators, which according to the fire safety requirements are not connected with people escape, except cases, when the elevators are specially meant for use in case of fire.

During a fire in tall buildings, a very rapid fumigation in the storeys of the building occurs. Temperature of combustion products that have flown into the staircase may exceed the maximal value allowable for human life. Thus, also analytical estimates should take into account that the allowable escape time directly depends on the time when hazardous factors of the accident start causing effect.

As the result of the study, it has been found out that these hazardous factors have the following critical values [19]:

- mean indoor air temperature $-70{ }^{\circ} \mathrm{C}$;

- thermal radiation $-500 \mathrm{~W} / \mathrm{m}^{2}$;

- concentration of toxic substances: $\mathrm{CO}-1.7 \mathrm{~g} / \mathrm{m}^{3}, \mathrm{CO}_{2}-$ $144 \mathrm{~g} / \mathrm{m}^{3}$

- oxygen content $-17 \%$;

- visibility deterioration through smoke - by 2.4 times.

For example, upon fire on $15 \mathrm{~m}^{2}-20 \mathrm{~m}^{2}$ floor area in an apartment on the second storey of a tall building already during the fifth minute after the burning has begun, temperature in the corridor between apartments may reach $280{ }^{\circ} \mathrm{C}-300^{\circ} \mathrm{C}$, in the staircase $-120^{\circ} \mathrm{C}-140^{\circ} \mathrm{C}$. "Heat cushion" with a high smoke temperature is formed in the staircase on the level of $2^{\text {nd }}-3^{\text {rd }}$ storey, which cannot be crossed without protective equipment.

\section{A. Analysis of Characteristic Quantities of Multi-Storey Residential House}

Construction of multi-storey residential building at 11 Lielirbes Street, Riga, began in 2006 and in 2007 the building was commissioned. This dwelling house has U1 fire grading, noncombustible roof, slabs, walls and 24 aboveground storeys and 2 underground storeys.

In terms of structural layout, it is featured as a skeleton-type building with typical elements. Structural description of the building: with bearing and confining structures of natural or artificial stone materials, concrete, reinforced concrete, with the use of noncombustible sheet.

The building is connected to urban power supply system while a fire pump with 2 standalone electric generators are installed in the technical room of the underground storey, these generators are automatically switched on in case of power outage.

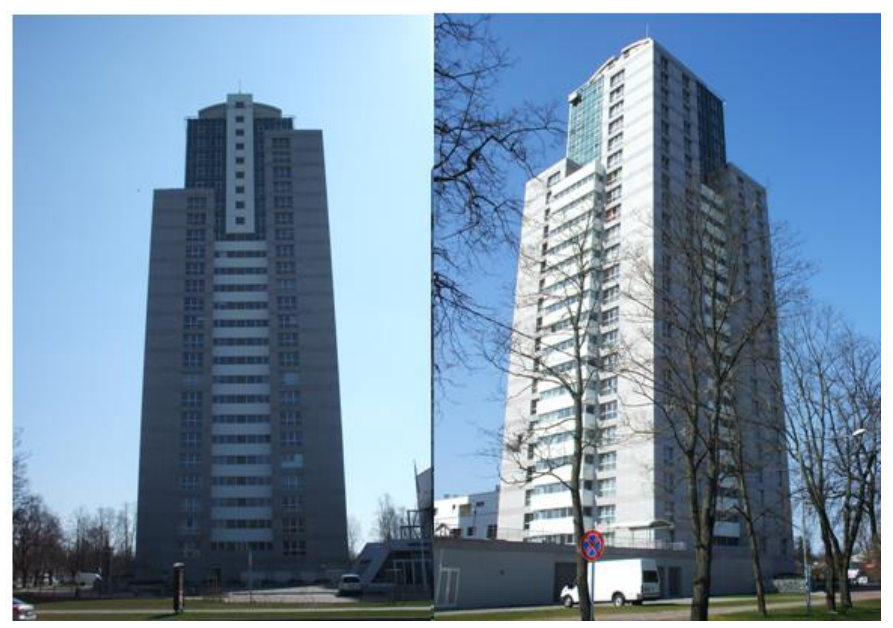

Fig. 2. Residential building "Panorāma Plaza" with indoor fire elevators.

\section{B. Description of Fire Hazard Areas in a Multi-Storey Residential Apartment House}

Planning and apartment layout of each of storeys 1 through 16 is the same. The total number of storeys is 24 plus 2 underground storeys where a car parking and technical storey are arranged.

In conditions of dense development, distance from one residential road of the dwelling house to the other one may not exceed 100 meters.

Walls between apartments should be made of noncombustible materials with fire-resistance time 30 minutes.

Combustibility group and fire-resistance time of gallery structures in a dwelling house should correspond to those of slab structures of the house.

Width of gate, car entrances and residential roads should not be less than 3.5 meters but their free height - less than 4.25 meters.

If a dwelling house has 16 or more storeys, double door lobby shall be provided. One staircase span should have not less than three and not more than 18 steps. Staircase spans and landings should be confined by handrails.

Staircases and elevator halls shall be separated from any other spaces by doors in accordance with Paragraph 5.3.4. of Latvian Building Normative LBN 201-96 "Fire safety norms".

In the apartments on the first, second, third, fourth and fifth storey, at least one exit shall be designed to a regular type 1 staircase in accordance with the requirements established by Latvian Building Normative LBN 201-96 "Fire safety norms". Apartments on the sixth, seventh, eighth and ninth storey need a second, escape exit that may be an exit from each apartment to the loggia (balcony) provided at least 1.2 meters wide wall section is left between the end wall of the loggia (balcony) and the window or door opening, while at least 1.6 meters wide wall section is left between the openings. Width of corridor outside the apartment should be at least 1.8 meters.

In corridor-type buildings, the corridor after each 30 meters shall be separated by partitions with built-in doors, automatic 
closing devices and sealed rabbet ledges. The doors should be without glazing or equipped with armoured glass. Partition and door structures should ensure smoke tightness.

The attic and the penthouse have a 1.2 meters wide walking area and 1.6 meters high passway throughout the building length.

Within two-meter long section its height is 1.2 meters and its width - one meter.

The attic of the building and each technical floor located in its middle part has two exits via common staircases in accordance with the requirements established by Latvian Building Normative LBN 201-96 "Fire safety norms".

\section{Description of Fire Prevention Systems in Tall Buildings}

The building is equipped with a smoke control system, indoor fire hydrants (which should ensure pressure specified in regulatory documents) in car parking, corridors, staircases and on technical floors, and with fire-extinguishing sprinkler system with water cooling, as well as with fire detection and alarm system.

Since it is a residential building and there was no possibility to arrange fire-extinguishing sprinkler systems in the apartments, the fire detection and alarm system with smoke and heat signaling sensors was installed in the apartments, allowing to rapidly respond in case of fire.

In this structure, the car parking, corridors, staircases and technical floors are equipped with the fire detection and alarm system, the smoke prevention system that is activated automatically upon response of the sensors.

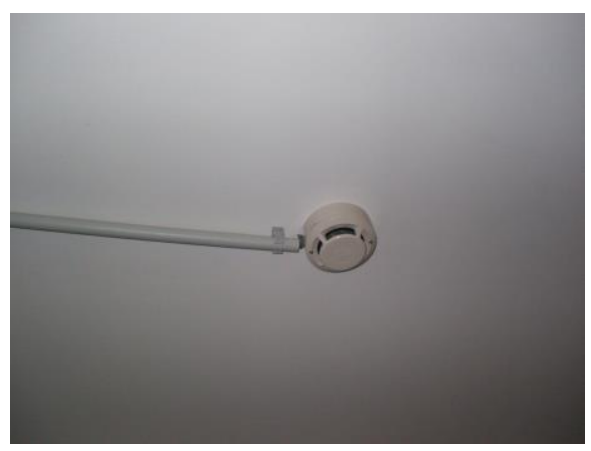

Fig. 3. Fire detection and alarm system.

Smoke prevention system provides a staircase, which has exits on each storey, with an open air area as well as with smoke offtake on a floor where fire has broken out $[2,3,4]$.

Pumps are installed on the technical floor, which are intended for water supply and provision of the fire extinguishing system, they are switchable not only automatically but also by means of a manual starting mechanism.

Since the structure in question has more than 17 storeys, two connection points to indoor fire extinguishing networks are arranged in order to install the fire extinguishing equipment.

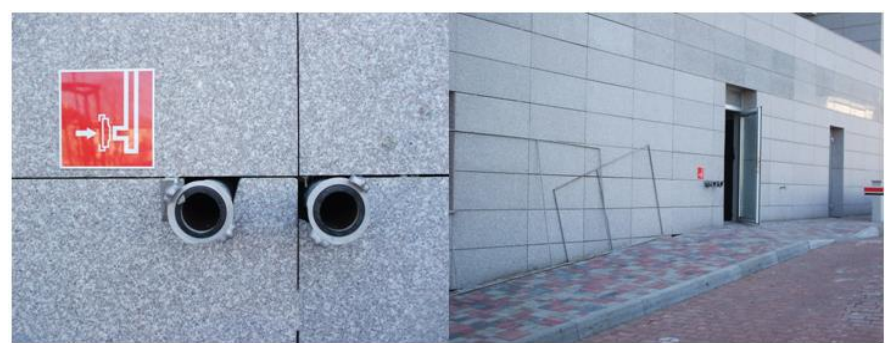

Fig. 4. Standpipes of indoor fire main.

The building is equipped with a fire public address system transmitting light, sound and voice notifications about how to act in order to organize a quick evacuation of people in accordance with the escape schedule. Upon fire signal from the fire extinguishing system and the elevator control console, the elevators are turned into the fire hazard mode. This signal can be delivered automatically or manually [5], [7].

When the signal is received, the elevators move down to the first store, with or without passengers, not stopping at the storeys called along the route, and upon arrival to the first storey the elevators open their doors and remain in place without possibility to move on, except the special fire elevators that usually are designed with the increased load lifting capacity in order to carry people or fire extinguishing equipment in case of fire.

Usually, elevators (those not intended for use in case of fire) are unsafe: elevator cage may become stuck between the storeys in the elevator well wherein the fire combustion products having a high temperature can get, and the elevator passengers may die. In case of fire, the elevators that are equipped with sensor call buttons and photocells in the elevator door are extremely dangerous. Sensor buttons may respond being lit by a match, lighter or flame of burning paper; besides, the elevator door will not shut if smoke appears on the way of the photocell light ray.

If the elevator cage is made of combustible materials, it may become an additional source of fuming in a tall building. As a result of high temperature, installation of power distribution cabinets is damaged, which leads to possible power outage and blocking of the elevator cage in the elevator well. As practice shows, the use of regular passenger elevators in case of fire may be the cause of passengers' death.

During a fire, panic may occur as well as a great flow of escaping people. Sometimes people jump out of the windows trying to survive.

As practice shows, temperature and hazardous concentration of toxic substances in the passages and staircases on the burning storey is reached already before all people are evacuated. According to statistical data, in $60 \%$ of cases poisoning with combustion products was the cause of people's death in tall buildings. Great danger is caused even by the effect of a weak toxic product. For example, irritation of lungs may occur at very low concentration of isocyanides, which cannot be detected even by air sampling. 


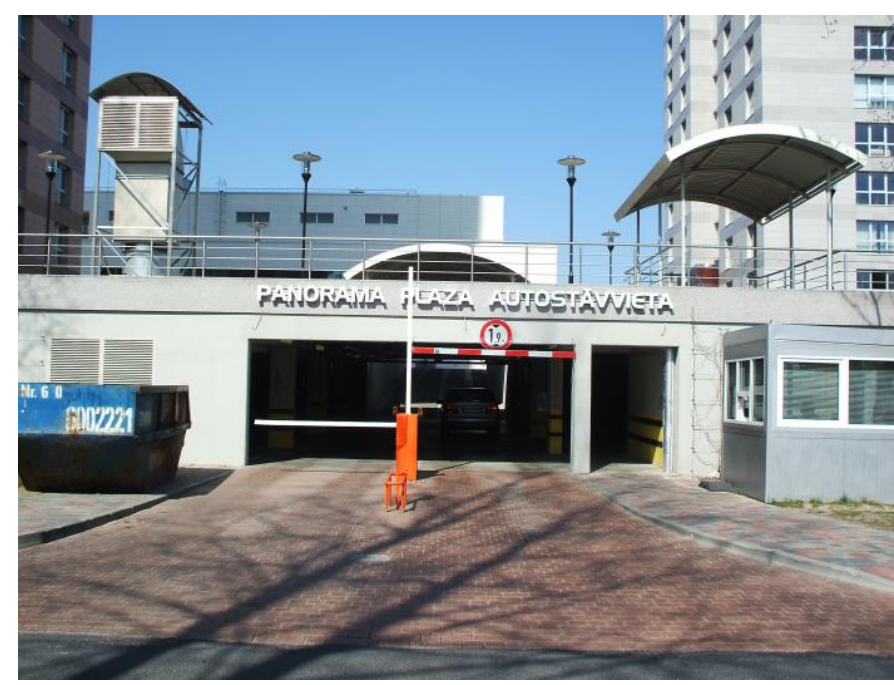

Fig. 5. Access roads at "Panorama Plaza".

It can be seen that he actual situation differs largely, therefore, the access to the object for the fire machinery as well as AK parking is only possible from the territory outside Ventspils Street.

\section{PERFORMANCE OF RESCUE WORKS IN TALl BUILDINGS}

Evacuation of people from a tall building during a fire is possible in two main ways $[8,9]$ :

1) use of technical facilities: AK facade elevators, specialized mobile rescue systems and aircraft.

2) use of technical facilities that operate on the principle of uniformly using the energy for load located at a height (pulse operation is equal to its counteraction): devices working by means of rope and jump shock-absorbing rescue devices (air inflated cushions, etc.).

There are three main types of rescue methods:

1) horizontal evacuation of a victim - moving the victim over the same storey where the fire outbreak has occurred to the next escape exit, which mainly implies the use of smokeless staircases, suspended cradles, outdoor section-tosection passages (loggias, balconies, stairways);

2) the second rescue method is downward movement and often $\mathrm{AK}$ is used, however, in this case the height of operation will be limited. To evacuate people from heights beyond reach of AK, auxiliary devices are used to take a victim to a height that can be reached by AK, such as hooked ladders, rescue ropes or windowsill-attachable rope ladders;

3) taking a rescued person upwards with the use of rescue ropes from a storey to a higher one or to the roof.

When using the rescue method with hooked ladder, the truck ladder is firstly put down in horizontal position and the hooked ladder is placed on the last section, which is then suspended at windows, loggias or balconies to reach the needed storey. The rescued person should be necessarily secured by a rescue rope.

When evacuating people by stairs and passages, the firemen shall be put in the escape routes to follow and help people getting to the escape exit, trying to prevent panic. For this purpose a voice fire alarm can be used to show the escape routes.

In case of fire in a building of 10 to 16 storeys (or up to $50 \mathrm{~m}$ height), one of elevators in the building can be adopted only for lifting the fire extinguishing and rescue equipment. The firemen walk to the burning storey with a measured tread in order not to hasten the occurrence of tiredness.

When being at one storey below the one under fire, a signal is given to lift the equipment by elevator. It should be taken into account that opening of windows is not desirable as a signaling because it generates additional airflow. In order to avoid human victims in the process of evacuation, as well as to prevent human intoxication with combustion products, the respiratory tract of a rescued person should be protected.

Evacuation of people from $4^{\text {th }}, 5^{\text {th }}$ and higher storeys can use portable fire ladders, forming a "chain" consisting of one extending ladder from the ground mark and more hooked ladders to the upper storeys. In order to carry out rescue works by this method, first of all a three-section extending ladder shall be installed, then the hooked ladders shall be suspended in windows, loggias or balconies to reach the needed storey. One fireman shall be put on each storey to hold the ladder and help the rescued people moving by the ladder. The rescued person should be necessarily secured by a rescue rope. In order to ensure stability of the hooked ladders, another hook can be mounted thereon at the same level, as well as the ladders can be fastened between themselves by belts when forming such "chain".

Correct transportation of a victim during the rescue works is of importance. The type of transportation is determined taking into consideration the situation, location of the victim and the nature of injuries, availability of special equipment, and transportation distance.

A victim is transported by one or more rescuers. The basic principles of victim transportation are as follows [19]:

- determination of transportation type;

- preparation of special transportation equipment;

- choice of escape route;

- safety provision for the victim and rescuers;

- obstacle crossing, control of victim's condition, rest pauses;

- delivery of the victim under care of a first aid medical worker or placing him/her in an emergency vehicle.

Victim transportation type shall be chosen taking into consideration the nature of injuries, their localization, the nature of disease. Correctly chosen transportation type can save life of the rescued victim, reduce victim's distress and ensure rapid convalescence. A victim can be transported lying on the back or stomach, side-lying or in a sitting position.

When evacuating people from the building's areas that are located above the operational reach of AK, people can be put on the building's roof, balconies and loggias at windward side of the building. In such cases, a fireman is commissioned in order to ensure human safety, prevent occurrence of panic, be together with the evacuees on the building's roof, on each balcony or loggia. 


\section{A. Fire Safety Solutions in Tall Buildings}

In order to ensure the safety of people in tall buildings, various fire safety measures are provided therein. Smokeproof staircases are provided for the evacuation of people, where people can only get crossing a smoke-free air zone (balcony).

If the tall building is a dwelling house and the total floor area of the apartments on a storey is $500 \mathrm{~m}^{2}$ and more, at least 2 smokeproof staircases are provided. Antismoke protection of staircases and elevator wells is also ensured by means of air supply with the use of fans, reaching $20 \mathrm{~Pa}-150 \mathrm{~Pa}$ overpressure in the protected spaces [2]. Exit to the building's roof is also provided from the staircases. Smoke from the corridors of the storeys is taken out via special wells, where a forced exhaust system and smoke valves are arranged.

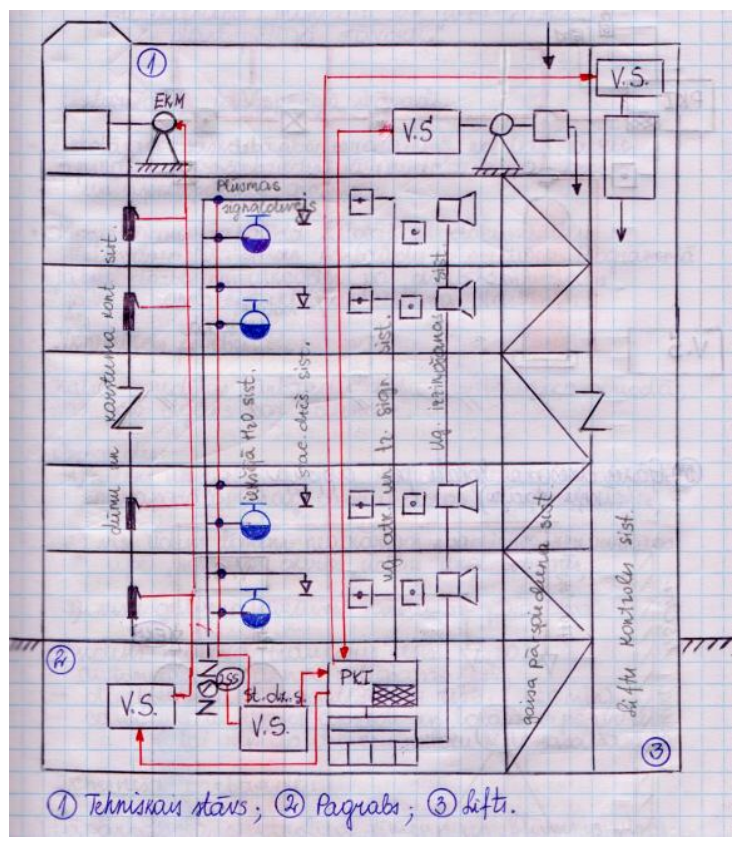

1 - technical floor; 2 - cellar; 3 - elevators

Flow signaling sensor

\begin{tabular}{|c|c|c|c|c|c|c|}
\hline 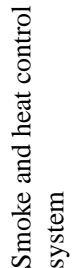 & 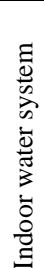 & ? & 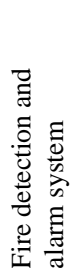 &  & 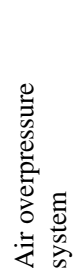 & 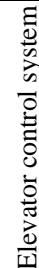 \\
\hline
\end{tabular}

Fig. 6. Schematic view of the fire protection system in tall buildings.

Automatic fire protection equipment in tall buildings shall ensure [6]:

- disconnection of the general ventilation mechanical device;

- switching on audio, voice and light public announcement equipment;

- activation of the mechanical smoke-deflecting system;

- activation of the air overpressure system in the elevator well, staircase or staircase exit enclosures;

- down trip of elevators to the first storey and door blocking in open position.
Fire elevators are installed in buildings with more than 16 storeys (or higher than $50 \mathrm{~m}$ counting from the planned ground level to the cornice).

In accordance with the provisions of the building normative LBN 201-96 "Fire safety norms", an automatic fire detection and alarm system shall be provided in all tall buildings, as well as an indoor water main with fire hydrants (hereinafter referred to as FH) should be located on storeys, while in public buildings an automatic sprinkler fire extinguishing installation and in-house fire voice announcement device should be additionally installed. In order to ensure the necessary pressure, fire extinguishing pressure booster pumps are installed, which are activated by remote control buttons located in or outside each FH cabinet.

In order to facilitate and speed up the rollout works during fire combat, a dry riser is made in some of tall buildings. It consists of a connection unit, upward metal pipe (usually 80Dn) and outlets on the storeys of the building, which are usually located in fire cabinets. Lower pipe of the dry riser contains a one-way valve and water drain valve.

\section{CONCLUSION}

The subject of the present study is a multi-storey residential apartment house. The analysis has been carried out on a multistorey building with the number of storeys over 10 (high-rise building), since just such buildings are characterized by increased fire hazard and more difficult fire extinguishing and rescue works. Within the framework of the performed study, one of the tall buildings in Riga has been analyzed: multistorey residential apartment building at 11 Lielirbes Street.

Each year fires occur in tall buildings and people die in Latvia and all over the word. Often the owner (manager) of a residential house or building also allows violations of fire safety since they cannot find a mutual compromise with the inhabitants, thus causing even more problems to the rescue service in saving the life of people who are within the residential areas, while the time necessary to get into an apartment is very precious for the people in the apartment or nearby.

Tall buildings are characterized by a rapid fire spread from one storey to another along the communications, windows, as well as within a storey where the fire has broken out, especially if the building has a corridor-type layout. Combustion products of the fire at great speed uprush along the staircases, elevator and technological wells, which during the fire act as smoke flues and create the "chimney effect" with upward draw, and, as a result of insufficient ventilation, layers of combustion products may be formed on top storeys.

Studying the existing regulatory base in the Latvian legislation, we have arrived at a conclusion that essential problems in this field are present, although Paragraph 6.7. of Regulation No. 82 of the Cabinet of Ministers of the Republic of Latvia of 17 February 2004 "Fire Safety Regulations", requires "... to assess the risk of possible fire and, basing on it, to develop and implement the fire safety measures at the project." The risk assessment for tall buildings in Latvia is a 
topical problem since new technologies open new opportunities, and therewith new problems appear.

Evacuation of people from a tall building during a fire is possible in two main ways:

1) use of technical facilities: AK facade elevators, specialized mobile rescue systems and aircraft;

2) use of technical facilities that operate on the principle of uniformly using the energy for load located at a height (pulse operation is equal to its counteraction): devices working by means of rope and jump shock-absorbing rescue devices (air inflated cushions, etc.).

In order to ensure the safety of people in tall buildings, various fire safety measures are provided:

1) Smokeproof staircases are provided for the evacuation of people, where people can only get crossing a smoke-free air zone (balcony).

2) If the tall building is a dwelling house and the total floor area of the apartments on a storey is $500 \mathrm{~m}^{2}$ and more, at least 2 smokeproof staircases are provided.

3) Antismoke protection of staircases and elevator wells is also ensured by means of air supply with the use of fans, reaching $20 \mathrm{~Pa}-150 \mathrm{~Pa}$ overpressure in the protected spaces.

4) Exit to the building's roof is also provided from the staircases.

5) Smoke from corridors of the storeys is taken out via special wells where a forced exhaust system and smoke valves are arranged.

\section{REFERENCES}

[1] The Skyscraper Centre, "The Global Tall Building Database of the CTBUH," [Online]. Available: http://skyscrapercenter.com/ [Accessed: Mar. 27, 2014.]

[2] V. Jemeljanovs, J. Sulojeva, M. Zielielis, J. Bartašauskis, O. Sniegovs, "Admine Evacuatiomn Time," Scientific journal of Riga Technical University, Safety of Technogenic Environment. Riga: RTU Press, 2012, vol. 2, ISSN-6923, pp. 5.

[3] V. Jemeljanovs, J. Sulojeva, I. Rusinovs, "Technological Disasters," Scientific journal of Riga Technical University, Safety or Technogenic Environment. Riga, RTU Press, 2012, vol. 3, ISSN-6923, pp. 11.

[4] V. Jemeljanovs, J. Sulojeva, J. Bartušauskis, "Analysis of the Interial Parameters of Fire Detectors," Scientific journal of Riga Technical University, Safety or Technogenic Environment, Riga, RTU Press, 2012, vol. 3, ISSN 225-6923, pp. 7.

[5] N. True, Computer Vision Based Fire Detection, University of California. San Diego: 2010, pp. 6.

[6] Fire Dynamic Tools, "Quantitative Fire Hazard Analysis Methods for the U.S. Nuclear Regulatory Commission Fire Protection Inspection program," 11 ch. - Estimating Smoke Detector Response Time, Washington, 2004.

[7] "Flame ionization Detectors: Applications and operations". Second Quarter 2009. [Online]. Available: www.specialtygasreport.com [Accessed: Mar. 27, 2014.].

[8] National Fire Protection Association, "NFPA 72 National Fire Alarm Code," 2002 ed. [Online]. Available: http://www.nfpa.org/codes-andstandards/document-information-pages? $m o d e=$ code $\&$ code $=72$ [Accessed: May 20, 2014.].

[9] "US National fire alarm code NFPA 72 and European standarts in the EN54 series - assessment of compatinility," BeClobal, May 27, 2010, pp. 33.
[10] CTIF International association, of fire and rescue service, "World fire statistics 2011," [Online]. Available: http://www.ctif.org/ctif/world-firestatistics [Accessed: June 21, 2014.]

[11] CTIF International association, of fire and rescue service, "World fire statistics 2012," [Online]. Available: http://www.ctif.org/ctif/world-firestatistics [Accessed: June 21, 2014.].

[12] CTIF International association, of fire and rescue service, "World fire statistics 2013," [Online]. Available: http://www.ctif.org/ctif/world-firestatistics. [Accessed: June 21, 2014.].

[13] Noteikumi Nr. 318 par Būvnormatīvu LBN 201-96 „Ugunsdrošības normas," Latvijas Republikas Ministru kabinets, Rīga, 1996.

[14] Noteikumi Nr. 411 par Būvnormatīvu LBN 208-00 „Publiskās ēkas un būves," Latvijas Republikas Ministru kabinets, Rīga, 2000.

[15] Noteikumi Nr. 409 par Būvnormatīvu LBN 211-98 „Daudzstāvu daudzdzīvokḷu dzīvojamie nami," Latvijas Republikas Ministru kabinets, Rịga, 1998.

[16] V. P. Ivannikov, P. P. Klûs, Spravočnik rukovoditelâ tušeniâ požara. Moskva: Ctrojizdat, 1987, pp. 159-184 (in Russian).

[17] Â. S. Povzik, Spravočnik rukovoditelâ tušeniâ požara. Moskva: ZAO Spectehnika, 2000, pp. 230-233 (in Russian).

[18] I. F. Kimstač, P. P. Devlišev, N. M. Evtûškin, Požarnaâ taktika. Moskva: Ctrojizdat, 1984, pp. 297-312 (in Russian).

[19] N. G. Klimušin, Tušenie požarov $v$ zdaniâh povyšennoj ètažnosti. Moskva: Ctrojizdat, 2010, pp. 4-17 (in Russian).

[20] S. K. Šojgu, A. F. Kudinov, S. A. Neživoj, i dr., Učebnik spasatelâ. Moskva: MČS Rossii, 2014, pp. 214-230 (in Russian).

Jeḷena Malahova is an Assistant Manager for the Study Process with the Institute of Labor Protection and Civil Defence and a Lecturer with Riga Technical University. In 2011, she received the Doctoral degree in Economics (Dr. oec.) from Riga Technical University. She has been a member of the board at SVD Group, Ltd. (2010-2011), Assistant Professor and Head of Business Department with the Latvian Business College (2008-2010).

Address: 6 Kalnciema Str., Riga, LV-1048, Latvia.

E-mail: jelena.sulojeva@ rtu.lv

Kārlis Ketners received the Dr. oec. degree from Riga Technical University in 1999.

$\mathrm{He}$ is currently a Professor with the Department of Customs and Taxes, Faculty of Engineering Economics and Management, Riga Technical University. From 1997 to 2006 he was a civil servant with the Ministry of Finance. His last positions were Director of Budget Department, Ministry of Finance of the Republic of Latvia, and Director General of the State Revenue Service of the Republic of Latvia. His main fields of scientific interest are: taxation, public administration and state policy improvement. He is author of numerous text books on tax policy and corporate tax planning issues.

Address: Department of Customs and Taxes, Faculty of Engineering Economics and Management, Riga Technical University, Kalnciema Str., 6, Riga, LV-1048, Latvia

E-mail: Karlis.Ketners@rtu.lv

Jānis Ieviňš received the $D r$. oec. degree from Riga Technical University in 1993. Professor, He is currently Head of the Institute of Labor Safety and Civil Defence of the Faculty of Engineering Economics and Management Riga Technical University. He delivers lectures on work safety, management and economics. He specializes in work safety and economic aspects of labor protection, as well as risk assessment. He is an Ambassador of the European Network Education and Training in Occupational Safety and Health (ENETOSH).

Address: Riga Technical University, Kalnciema Str., 6, Riga, LV-1048, Latvia. Tel: +371 29272394.

E-mail: Janis.Jevins@rtu.lv

Mihails Antonovs received the qualification of Fire Protection and Civil Defence Engineer from Riga Technical University in 2014. He works as an Inspector at the State Fire and Rescue Service of Latvia, in Administration of Jurmala Region for Fire Monitoring and Civil Protection.

Address: Maskavas Str., 3, Riga, LV-1050, Latvia.

E-mail: Mihails.Antonovs@ vugd.gov.lv 